\title{
Serum oxidative stress is increased in patients with post cholecystectomy bile duct injury
}

\author{
A. G. Miranda-Díaz ${ }^{1}$, J. M. Hermosillo-Sandoval², G. G. Ortiz ${ }^{3}$, D. Lizardi-García ${ }^{4}$, \\ E. G. Cardona-Muñoz ${ }^{4}$ and F. Pacheco-Moisés ${ }^{5}$
}

${ }^{1}$ General Surgery. Centro Universitario de Ciencias de la Salud, Universidad de Guadalajara. Jalisco, México. ${ }^{2}$ General Surgery. Centro Médico Nacional de Occidente. Instituto Mexicano del Seguro Social. Guadalajara. Jalisco, México. ${ }^{3}$ Centro de Investigación Biomédica de Occidente. Instituto Mexicano del Seguro Social. Guadalajara, Jalisco. México. ${ }^{4}$ Centro Universitario de Ciencias de la Salud. Universidad de Guadalajara. Guadalajara, Jalisco. México. ${ }^{5}$ Engineering and Exact Sciences. Centro Universitario de Ciencias Exactas e Ingeniería. Universidad de Guadalajara. Jalisco, México

\begin{abstract}
Background: post-cholecystectomy bile duct injuries are identified by the onset of jaundice as well as elevated bilirubin and alkaline phosphatase levels during the peri-operative period. It is unknown how serum oxidative stress markers are modified in patients with post-cholecystectomy bile duct injuries.

Objective: to determine serum oxidative stress marker levels (lipid peroxidation by-products, nitrites/nitrates and total antioxidant capacity) in patients with post-cholecystectomy bile duct injuries.

Patients and methods: a prospective, transversal and analytical study was designed with two groups. Group 1: 5 healthy volunteer subjects. Group 2: 52 patients with post-cholecystectomy bile duct injuries ( 43 female and 9 male). An elective bilio-digestive reconstruction was performed at week 8 . The serum oxidative stress marker levels were quantified by colorimetric method.

Results: patients with bile duct injuries had a significant increased serum lipid peroxides (malondialdehyde and 4-hydroxyalkenals) and nitric oxide metabolites (nitrites/nitrates) levels compared to the control group. In contrast, total antioxidant capacity in patients with bile duct injuries remained similar compared to healthy controls.

Conclusions: the results show that oxidative stress is usually associated to bile duct injury.
\end{abstract}

Key words: Bile duct injury. Oxidative stress. Cholecystectomy.

Financial support: Grant CONACYT SALUD-2005-CO1-13801.

Received: 13-10-09.

Accepted: 22-01-10.

Correspondence: Alejandra G. Miranda-Díaz. Av. La Paz No. 2758, Col. Arcos Sur 44320. Guadalajara, Jalisco. México. e-mail: alexmiranda1@hotmail.com

\section{RESUMEN}

Introducción: las lesiones de las vías biliares postcolecistectomía se establecen por la aparición de ictericia, elevación de las bilirrubinas y de la fosfatasa alcalina durante el periodo perioperatorio. Se desconoce cómo se modifican los marcadores de estrés oxidativo en el suero de los pacientes con lesiones de las vías biliares postcolecistectomía.

Objetivo: determinar los marcadores de estrés oxidativo (productos de peroxidación de lípidos, catabolitos del óxido nítrico y capacidad antioxidante total) en el suero de pacientes con lesiones de las vías biliares.

Pacientes y métodos: se realizó un estudio prospectivo transversal analítico. Se formaron 2 grupos de estudio. Grupo 1: 5 voluntarios sanos que sirvieron como control. Grupo 2: $52 \mathrm{pa}-$ cientes con lesiones de las vías biliares postcolecistectomía (43 femeninos y 9 masculinos). La reconstrucción bilio-digestiva se realizó de manera electiva a las 8 semanas. Los niveles séricos de los marcadores de estrés oxidativo se cuantificaron mediante métodos colorimétricos.

Resultados: los niveles séricos de los productos de peroxidación de lípidos (malondialdehído y 4-hidroxialquenos) y de los catabolitos del óxido nítrico (nitritos/nitratos) aumentaron significativamente en los pacientes con lesiones de las vías biliares en comparación a los voluntarios sanos. En contraste, la capacidad antioxidante total en el suero de los pacientes con lesiones de las vías biliares fue similar a la de los voluntarios sanos.

Conclusiones: los resultados muestran que el estrés oxidativo en suero es un componente que se asocia a las lesiones de las vías biliares.

Palabras clave: Lesión de vías biliares. Estrés oxidativo. Colecistectomía.

Miranda-Díaz AG, Hermosillo-Sandoval JM, Ortiz GG, LizardiGarcía D, Cardona-Muñoz EG y Pacheco-Moisés F. Serum oxidative stress is increased in patients with post cholecystectomy bile duct injury. Rev Esp Enferm Dig 2010; 102: 352-356 


\section{INTRODUCTION}

Post-cholecystectomy bile duct injuries (BDI) produces extra-hepatic cholestasis and are identified by the presence of jaundice as well as elevated liver enzymes, bilirubin and alkaline phosphatase levels $(1,2)$. As confirmed by reports of experiments carried out in rats that underwent choledocal obstruction producing chronic cholestasis with an increase in malondialdehyde levels (3), oxidative stress plays a key role in the pathogenesis of a different hepatic conditions.

Under normal conditions $1-4 \%$ of the oxygen $\left(\mathrm{O}_{2}\right)$ that reaches cells becomes reactive oxygen species (ROS) which can be easily neutralized by intracellular and mitochondrial antioxidant systems (4). Oxidative stress is the result of the lack of balance between ROS production and antioxidants agents (5). ROS are hepatotoxic as they interact with a number of macromolecules and nucleic acids producing enzyme inactivation, lipid peroxidation, and finally cell membrane damage (6). The alteration produced by free radicals activates the monocyte/macrophage systems as well as neutrophils. The superoxide anion $\left(\mathrm{O}_{2 .-} .^{-}\right)$is attributed proinflammatory properties consisting in neutrophils recruiting, release of chemotactic factors and pro-inflammatory mediators like TNF- $\alpha$ and IL-1, damaging nucleic acids and initiating lipid peroxidation (7).) A free radical is capable of oxidating several lipid molecules and starting chain reactions which precede cell membrane injury (8).

Nitric oxide (NO) plays a dual role as an oxidative and anti-oxidative factor (9). As an antioxidant, NO protects cells from oxidative stress (10). Nevertheless, an excess in $\mathrm{NO}$ enables it to behave as a pro-oxidative factor $(11,12)$.

Serum total antioxidant capacity reflects its ability to prevent damage induced by free radicals. On the other hand, oxidative stress could also play a favorable role during inflammatory response by inducing: cell proliferation, gene activation, and apoptosis; however, it is not clear at which point these events become deleterious rather than beneficial (13). It remains to be determined which markers of oxidative stress are related to the clinical outcomes in patients that presented BDI.

The objective of this study was to determine serum levels of lipid peroxidation products, nitric oxide metabolites, and total antioxidant capacity in patients with post-cholecystectomy bile duct injuries.

\section{PATIENTS AND METHODS}

A cross sectional analytic study which included 2 groups was carried out.

-Group 1 (control): 5 healthy volunteers were included, 4 female and 1 male, whose age was similar to that of those included in group 2. A $5 \mathrm{~mL}$ peripheral blood sample was extracted, from which serum was obtained and stored at $-80{ }^{\circ} \mathrm{C}$ for further use.

- Group 2: 52 patients with BDI, characterized by complete biliary obstruction, were included. These patients were all derived to the Surgery Department in the Specialties Hospital of the Western National Medical Center of the Social Security Institute of Mexico, where, according to the patient's characteristics, the most convenient bilio-digestive reconstructive surgery was practiced. The procedure was realized electively, 8 weeks after the acute episode, during which external biliary drainage was performed on all subjects. Normal coagulation tests were required to minimize bleeding risk and total blood, fresh frozen plasma and $\mathrm{K}$ vitamin were available during surgery. A $5 \mathrm{~mL}$ blood sample was obtained immediately before anesthetic induction and surgical procedure, extracting serum and storing it at $-80^{\circ} \mathrm{C}$ for its further use.

Lipid peroxidation products, NO metabolites and total antioxidant capacity were quantified to determine their behavior in patients with BDI about to undergo bilio-digestive reconstruction.

\section{Clinical manifestations}

Forty three females and 9 males with BDI were included, all in a productive stage in life with a mean age of 46.6 years. The BDI were secondary to 30 open and 22 laparoscopic cholecystectomies. Hepp-Couinaud and $\mathrm{Y}$ de Roux reconstructive procedures were performed on each patient and the average surgical time was 6.5 hours. All patients received artificial nutrition prior to surgical reconstruction.

\section{Lipoperoxidation products}

Lipid peroxidation products were assayed using the kit FR12 peroxides (Oxford Biomedical Research, Oxford MI, USA) containing a cromogen (N-methylphenylindol) which reacts with lipid peroxides (malondialdehyde and 4-hydroxyalquenes) at $45{ }^{\circ} \mathrm{C}$ producing a stable compound with a maximum absorbance at 586 $\mathrm{nm}$.

\section{Nitrites/nitrates}

In order to quantify $\mathrm{NO}$ metabolites, serum samples were deproteinized as established by Ghasemi et al. (14), and then we used the 482650 (Merck, Darmstadt, Germany) reagent kit according to the manufacturer's instructions. The results obtained were expressed as $\mu \mathrm{M} / \mathrm{mL}$. 


\section{Total antioxidant capacity}

Total antioxidant capacity was measured using the TA01 (Oxford Biomedical Research, Oxford MI, USA) reagent kit. The combined capacity of serum antioxidants reduces $\mathrm{Cu}^{+2}$ to $\mathrm{Cu}^{+1}$ which then reacts with the chromogen batocuproin to produce a stable compound with a maximum absorbance of $490 \mathrm{~nm}$. The results are expressed as $\mathrm{nM} / \mathrm{mL}$ uric acids equivalents.

\section{Ethical considerations}

The study abided by the Helsinki declaration updated in 2000 as well as with local and national law. Patients were identified with a number in order to guarantee confidentiality. Both the protocol and the informed consent forms were revised and approved by the Specialties Hospital of the Western National Medical Center ethics committee.

\section{Statistical analysis}

Central tendency and dispersion analysis were realized. Student's t test was used to measure inter-group differences. SPSS (version 10, Chicago IL) software for windows was used. Any difference was accepted as significant with a value of $p \leq 0.05$, with a $95 \%$ confidence interval.

\section{RESULTS}

\section{Clinical manifestations}

Female to male ratio was $4: 1$. All patients had jaundice, repetitive cholangitis episodes, an increase in body temperature, nausea, vomiting and weight loss prior to surgical reconstruction. The majority of patients were in a productive age with a high risk of serious complications and premature death.

\section{Peroxidation products}

Patients that presented BDI had an increase in serum lipid peroxide products (malondialdehyde, 4-hydroxyalkenes) levels compared to the control group (2.289 $\pm 0.610 \mathrm{nmol} / \mathrm{mL}$ vs. $1.441 \pm 0.544 \mathrm{nmol} / \mathrm{mL} ; \mathrm{p}<$ 0.0041 Student's t test) (Fig. 1A).

\section{Nitrites/nitrates}

The serum levels of NO metabolites in the BDI group were greater than those found in the control group $(094 \pm 0.00 \mu \mathrm{mol} / \mathrm{L}$ vs. $0.057 \pm 0.014 \mu \mathrm{mol} / \mathrm{L} ; \mathrm{p}$ $<0.0001$ Student's t test) (Fig. 1B). It is relevant to mention that although the difference in nitrite levels was small, its great capacity to diffuse renders it capable of producing important systemic effects.

\section{Total antioxidant capacity}

Total antioxidant capacity reflects the ability of serum to prevent free radical induced damage. Its value in the BID group was quite similar to that in the control group $11.0 \pm 0.48 \mathrm{nM} / \mathrm{mL} v s .11 .6 \pm 2.86 \mathrm{nM} / \mathrm{mL}$. This similar total antioxidant capacity could be a consequence of the short time between the cholecystectomy, the accidental biliary duct injury and the reconstructive surgery. It could also be due to the total bilirubin level $(5.42 \pm 3.46 \mathrm{mg} / \mathrm{dL})$ which could have interfered with

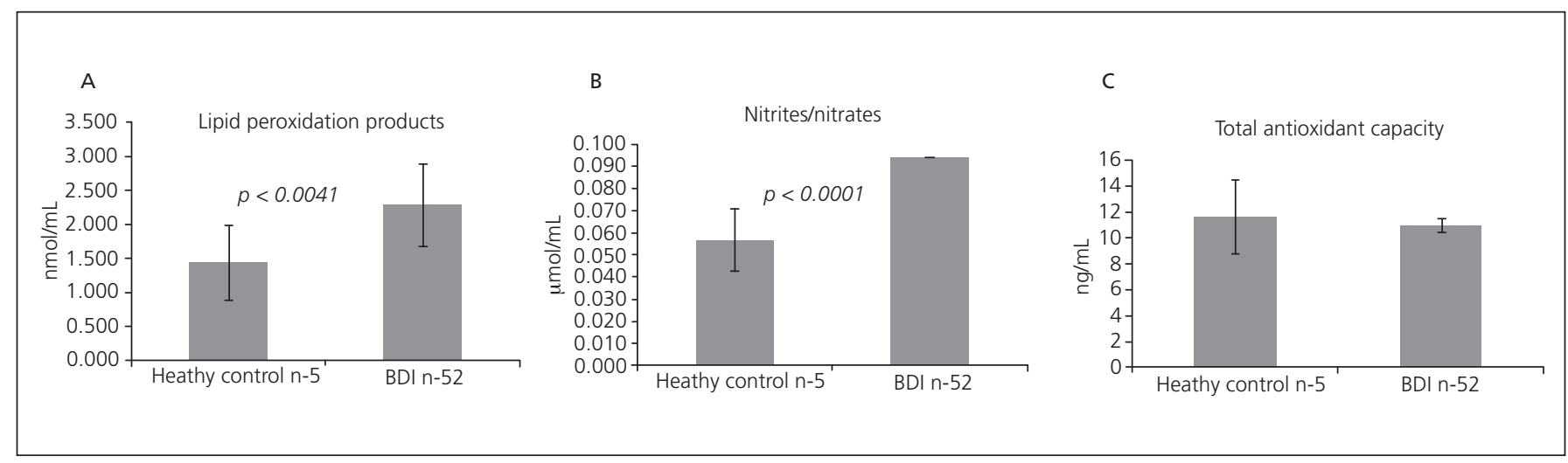

Fig. 1. Lipoperoxides, nitrites/nitrates and total antioxidant capacity. A. Production of lipoperoxides was significantly higher in patients with post-cholecystectomy bile duct injury compared to healthy controls. B. Nitrites/nitrates levels were also higher in the treatment group compared to controls. C. We expected a decreased total antioxidant capacity in patients with bile duct injury but there was no statistical difference between groups. This could be due to an effective systemic compensatory effect or to the interference from high total bilirubin levels. 
the final result. Finally, this could be due to the capacity of the organism to compensate for the increase in lipid peroxides and NO metabolites (Fig. 1C).

\section{DISCUSSION}

Bile duct injuries occur most commonly during a cholescystectomy, their severity depends on the type of injury, the degree of obstruction, time to diagnosis and the number of attempts to treat the problem (15). The present study included 52 patients, most of them women in a productive age. Serum markers of oxidative stress (lipid peroxides and nitrites/nitrates) and total antioxidant capacity were measured in both the control and the BDI group.

It is well know that biliary stasis and the increase in biliary salts augment intracellular oxidative stress and it may induce a necrotic type cell death. Hepatocellular injury is worsened by the effect of hydrophobic bile salts (16). Lipid peroxidation by-products were increased in the BDI group. Concerning this, we ignore what was the influence of these by-products in the increased fibrogenic molecules, like transforming growth factor $\beta$ (TGF- $\beta$ ) in serum or liver tissue, or in the deposit of collagen type I and III in extracellular matrix in patients with BDI, as our group has recently reported (17). On the other hand, the present study shows a significant increase in indirect NO activity markers, like nitrites/nitrates, in patients with BDI, which detrimental effects should be taken into consideration. NO is produced through the oxidation of arginine and citruline by a chemical reaction catalyzed by the enzyme nitric oxide synthase (NOs), present in hepatocytes, Kupffer cells and peritoneal neutrophils. During sepsis, the presence of endotoxins and cytokines induce NOs activity in the endothelium, vascular smooth muscle cells and in other cells and tissues, producing vasodilatation that surpasses vasoconstrictor activity, and, finally, culminating in endothelial damage (18). This could be a similar condition to that present in complete biliary obstruction. Taking the previous results into consideration, the lack of statistical difference regarding total antioxidant capacity called our attention. This lack of difference could be due to several causes: a) the time lapse between cholecystectomy, accidental BDI and bilio-digestive reconstruction was short; b) the compensatory response of the organism to aggression; and c) persistently elevated total bilirubin, which was not normalized prior to surgical reconstruction. This could have influenced the result; as reported by Pascual et al. (19). Total antioxidant capacity in septic patients did not differ from that of control patients, which could be caused by the elevated total bilirubin levels. In conclusion, oxidative stress is an important component in patients suffering of BDI.
We concur that the management of patients with BDI should be done in third level care hospitals, with skilled surgeons, guaranteeing a lower complication and mortality incidence in these patients (20).

It is also important to evaluate the expression of pro-inflammatory cytokines (TNF- $\alpha$, IL-6) and the behavior of several molecules involved in apoptosis associating the results with clinical manifestations.

\section{REFERENCES}

1. Chapman WC, Halevy A, Blumgart LH, Benjamin IS. Postcholecystectomy bile duct strictures. Management and outcome in 130 patients. Arch Surg 1995; 130(6): 597-602.

2. Pérez FT, López SP, Tomás E, Gutiérrez ML, Lledó JL, Cacho G, et al. Diagnostic and therapeutic approach to cholestatic liver disease. Rev Esp Enferm Dig 2004; 96(1): 60-73.

3. Cruz A, Tasset I, Ramírez LM, Arjona A, Segura J, Túnez I, et al. Effect of melatonin on myocardial oxidative stress induced by experimental obstructive jaundice. Rev Esp Enferm Dig 2009; 101(7): 460-3

4. Solís HJA, Solís MP. Melatonin and oxidative stress. Rev Esp Enferm Dig 2009; 101(7): 453-9.

5. Andresen HM, Regueira HT, Leighton F. Oxidative stress in critically ill patients. Rev Med Chil 2006; 134(5): 649-56.

6. Bienert GP, Schjoerring JK, Jahn TP. Membrane transport of hydrogen peroxide. Biochim Biophys Acta 2006; 1758(8): 994 1003.

7. Arthur MJ, Bentley IS, Tanner AR, Saunders PK, MillwardSadler GH, Wright R. Oxygen-derived free radicals promote hepatic injury in the rat. Gastroenterology 1985; 89(5): 111422 .

8. Yamamoto Y, Niki E, Kamiya Y, Miki M, Tamai H, Mino M. Free radical chain oxidation and hemolysis of erythrocytes by molecular oxygen and their inhibition by vitamin E. J Nutr Sci Vitaminol 1986; 32(5): 475-9.

9. Albrecht EW, Stegeman CA, Heeringa P, Henning RH, van Goor $\mathrm{H}$. Protective role of endothelial nitric oxide synthase. J Pathol 2003; 199(1): 8-17.

10. Mohanakumar KP, Thomas B, Sharma SM, Muralikrishnan D, Chowdhury R, Chiueh CC. Nitric oxide: an antioxidant and neuroprotector. Ann N Y Acad Sci 2002; 962: 389-401.

11. Erusalimsky DJ, Moncada S. Nitric oxide and mitochondrial signaling from physiology to pathophysiology. ATVB 2007; 27: 2524-31

12. Yamakura F, Taka H, Fujimura T, Murayama K. Inactivation of human manganese-superoxide dismutase by peroxynitrite is caused by exclusive nitration of tyrosine 34 to 3-nitrotyrosine. J Biol Chem 1998; 273(23): 14085-9.

13. Galley HF, Davies MJ, Webster NR. Xanthine oxidase activity and free radical generation in patients with sepsis syndrome. Crit Care Med 1996; 24(10): 1649-53.

14. Ghasemi A, Hedayati M, Biabani H. Protein precipitation methods evaluated for determination of serum nitric oxide end products by the Greiss Assay. JMSR 2007; 2: 29-32.

15. Way LW, Stewart L, Gantert W, Liu K, Lee CM, Whang K, et al Causes and prevention of laparoscopic bile duct injuries: analysis of 252 cases from a human factors and cognitive psychology perspective. Ann Surg 2003; 237(4): 460-9.

16. Muntané J, González R, Ranchal I, Collado JA, López-Sánchez LM, Herencia C, et. al. Mechanisms of liver cell injury. Rev Esp Enferm Dig 2007; 99(7): 405-10.

17. Alatorre-Carranza MP, Alejandra Miranda-Díaz A, Irinea YañezSánchez I, Oscar Pizano-Martínez O, Hermosillo-Sandoval JM, Vázquez-Del Mercado M, et al. Liver fibrosis secondary to bile duct injury: correlation of Smad7 with TGF- $\beta$ and extracellular matrix proteins. BMC Gastroenterol 2009: 9: 81 . 
18. Carrizo PH, Dubin M, Stoppani AO. Physiopathologic effects of nitric oxide and their relationship with oxidative stress. Medicina 1998; 58(4): 367-73

19. Pascual C, Karzai W, Meier-Hellmann A, Oberhoffer M, Horn A, Bredle D, et al. Total plama antioxioxidant capacity is not always decreased in sepsis. Medicina 1998; 58(4): 367-73.

20. de Reuver PR, Grossmann I, Busch OR, Obertop H, van Gulik TM, Gouma DJ. Referral pattern and timing of repair are risk factors for complications after reconstructive surgery for bile duct injury. Ann Surg 2007; 245(5): 763-70. 